\title{
Isolation and characterization of Staphylococcus aureus from bovine mastitis in Andhra Pradesh
}

\author{
P Madhava $^{1}$, D Rani Prameela ${ }^{1}$, B Sreedevi ${ }^{2}$ and T Madhava Rao ${ }^{3}$
}

Received: 11 February 2021 / Accepted: 24 July 2021 / Published online: 31 October 2021

(c) Indian Dairy Association (India) 2021

\begin{abstract}
Staphylococcus aureus is the key causative agent for contagious mastitis and responsible for subclinical infections leading to economic loss to dairy industry worldwide. Hence, the present work was planned to isolate and characterize the Staphylococcus aureus from bovine mastitis cases of $S$. aureus origin. From non therapeutic areas, a total of 381 staphylococcal isolates were recovered out of 438 milk samples with percentage positivity of 86.98 , whereas, out of 60 milk samples in selected therapeutic areas 40 staphylococcal isolates with positivity of $66.67 \%$ were recovered based on cultural and biochemical tests. A total of 290 out of 381 and 30 out of 40 culturally positive isolates respectively from non therapeutic and therapeutic areas were confirmed as S. aureus by PCR method targeting the $16 \mathrm{~S}$ rRNA with an expected amplicon size of 229bp. Sequencing and nucleotide analysis of $16 \mathrm{~S}$ rRNA amplicons of non therapeutic area isolates showed $99.3 \%$ identity whereas therapeutic isolates showed $95-100 \%$ identity with gene bank reference strains. On phylogenetic analysis, isolates form non therapeutic area were not closely related to reference gene bank strains whereas isolates of therapeutic area were shown close evolutionary relationship with gene bank reference strains. Further, Peruru isolates of therapeutic area have shown close evolutionary relationship with Spain isolate KX348312.1 and formed separate group in cladogram.
\end{abstract}

\footnotetext{
${ }^{1}$ State Level Diagnostic Laboratory, SVVU, Tirupati-517502, Andhra Pradesh, India

Email: madhavapolu42@gmail.com

${ }^{2}$ Department of Microbiology, College of Veterinary Science, Tirupati517502, Andhra Pradesh, India

Email: bollinisreedevi@gmail.com

${ }^{3}$ Department of Veterinary public Health, CVSc, Tirupati-517502, Andhra Pradesh, India

D Rani Prameela $(\square)$

State Level Diagnostic Laboratory, Sri Venkateswara Veterinary University, Tirupati, 517502, AP, India

E-mail: raniprameela.dr@gmail.com
}

Keywords: Contagious mastitis, Staphylococcus aureus, Subclinical mastitis, 16srRNA, Phylogenetic analysis

Introduction: Mastitis is the predominant intra mammary infection in dairy cattle in India causing huge economic loss to the dairy industry. Both clinical and subclinical bovine mastitis are responsible for reduction in milk production, deterioration of quality of milk and milk products, increased amount of health care expenditure, financial loss due to culling of sick animals and even mortality of cows. $S$. aureus is the major contagious agent of bovine mastitis. S. aureus is the most important and lethal agent (Jaradat et al. 2014) causing chronic and deep infections in mammary tissue and becomes difficult to treat successfully and is responsible for dairy scourge in the livestock industry (Husain et al. 2012a; Raza et al. 2013). It originates from the cows environment and infect the udder via the teat canal (Padhy et al. 2014). The staphylococci have been adapted to survive in the udder, usually establish chronic, subclinical infection and are shed in the milk becoming the source of infection for other healthy cows during milking process. The main source of infections for $S$. aureus mastitis is the udder of infected cows which is transferred via milkers hands, utensils, towels and the environment (floor) where the cows are kept (Radostitis et al. 2007).

The bacterial culturing of the raw milk is the standard procedure for diagnosis of the bacterial pathogens, but the method is time consuming. Several approaches regarding phenotyping and genotyping are being used to subtype the $S$. aureus isolates recovered from animals and human (Kalorey et al. 2007; Saei et al. 2009). The molecular diagnosis could be the most suitable technique for the identification of various circulating strains of pathogens which are difficult to identify by conventional methods. The molecular based techniques are much effective in pursuing the spread of bacterial infections and developing diagnostic methods. The 16S rRNA genes are highly conserved throughout bacterial evolution; hence it was targeted for molecular identification of $S$. aureus using PCR method.

Extensive and indiscriminate use of antibiotics in the treatment and control of mastitis lead to accumulation undesirable of drug residues in milk, emergence of antibiotic resistant bacteria and 
necessary withholding period. To avoid indiscriminate use of antibiotics and to reduce the cost of treatment, practice of antibiotic sensitivity testing should be adopted before initiation of treatment. Antimicrobial therapy is a primary tool for controlling Staphylococcal mastitis. Wide spread and indiscriminate use of antimicrobial agents has resulted in the emergence and transfer of resistant organisms to humans through milk. The emergence of resistance to antibiotics in gram-positive pathogens has become a major global issue (WHO, 2015). Hence, the present study was undertaken to isolate and identify $S$. aureus from bovine mastitis cases by both cultural and molecular methods. Further, antibiogram of the recovered $S$. aureus isolates was conducted to know the antibiotic of choice, sensitivity and resistance pattern for effective treatment and control of mastitis.

\section{Materials and Methods}

\section{Collection of milk samples}

A total of 498 milk samples were collected randomly from milch cattle in non therapeutic and therapeutic areas of Andhra Pradesh during the period from November, 2017 to July, 2018 shown in Table 1.

\section{Isolation and Identification of Staphylococcus aureus}

\section{Processing of mastitis milk samples}

Milk samples from bovine mastitis cases were subjected for isolation and identification of Staphylococcus aureus using conventional and cultural isolation methods. The collected milk samples were inoculated into BHI broth $(5 \mathrm{ml})$ and incubated at $37^{\circ} \mathrm{C}$ for $24 \mathrm{hrs}$ (Cruickshank et al. 1975). After incubation a loopful of inoculated broth culture was streaked on to the selective differential media like Blood agar, MacConkey's agar and selective media like Mannitol salt agar media and incubated at 37 ${ }^{\circ} \mathrm{C}$ for $48 \mathrm{hrs}$ in incubator and observed for morphology, cultural characteristics, Gram's staining, Biochemical confirmation by Catalase, Oxidase and Coagulase tests etc (Quinn et al. 2004).

\section{Extraction of bacterial DNA}

Table 1 Details of the milk samples screened against subclinical \& clinical mastitis in non therapeutic and therapeutic areas of Andhra Pradesh

\begin{tabular}{llll}
\hline Area & $\begin{array}{l}\text { No. of milk samples } \\
\text { collected }\end{array}$ & $\begin{array}{l}\text { No. of milk samples tested } \\
\text { positive }\end{array}$ & Percent Positive \\
\hline Non Therapeutic area & 438 & 381 & 86.98 \\
Therapeutic area & 60 & 40 & 66.67 \\
Total & 498 & 421 & \\
\hline
\end{tabular}

Table 2 Details of Oligonucleotide primers for amplification of 16SrRNA gene of Staphylococcus aureus

\begin{tabular}{llll}
\hline Target Gene & Primer Sequence (5'-3') & Amplicon Size (bp) & Reference \\
\hline 16S rRNA & 16S-F-GTAGGTGGCAAGCGTTACC & 229 & Lovesth et al. 2004 \\
& 16S- R CGCACATCAGCGTCAG & & \\
\hline
\end{tabular}

DNA was extracted according to the method of Arora et al (2006). Single pure bacterial colony was picked and dissolved in $50 \mu 1$ of distilled water in $1.5 \mathrm{ml}$ eppendorf tubes. The mixture was boiled at $96^{\circ} \mathrm{C}$ for $8 \mathrm{~min}$ in water bath. The tubes were removed and immediately chilled by placing on to the ice for $10 \mathrm{~min}$. All the bacterial lysates were centrifuged at $10,000 \mathrm{rpm}$ for $5 \mathrm{~min}$ in refrigerated centrifuge at $4^{\circ} \mathrm{C}$. From this snap chilled bacterial lysate, the supernatant containing genomic DNA was collected

\section{Molecular Detection of Staphylococcus aureus}

The culturally and biochemically positive $S$. aureus isolates were further confirmed genotypic ally using PCR with genus specific primers according to method of Pati and Reena Mukherjee (2016).

\section{Primers}

Oligonucleotide primers were obtained from Sigma Aldrich Chemical India Pvt.Ltd., Bangalore. Details of the primer sequences are shown in Table 2.

\section{Polymerase chain reaction (PCR)}

The PCR method is standardized according to the method of Lovesth et al 2004. The total reaction volume was set up to $25 \mu \mathrm{l}$ consisting of $2.5 \mu 110 \mathrm{x}$ PCR buffer, $0.5 \mu 1$ of $10 \mathrm{mM}$ dNTP mix, 0.3 $\mu 1$ of Taq polymerase, $100 \mu \mathrm{M}$ concentration of forward and reverse primer $(0.5 \mu \mathrm{l}$ each), $1.5 \mu \mathrm{l}$ of $\mathrm{MgCl} 2(25 \mathrm{mM}), 3 \mu$ l of template DNA and remaining volume was made up with nuclease free water. The DNA template obtained by boiling and snap chilling extraction technique was subjected to PCR with genus specific primers, for the identification of $S$. aureus.

\section{Steps and thermal cyclic conditions for 16SrRNA gene PCR}

The amplification reactions were carried out in $0.2 \mathrm{ml}$ micro centrifuge tubes using programmable thermal cycler (Proflex PCR, applied bio-systems life technologies, Singapore) with initial denaturation at $95^{\circ} \mathrm{C}$ for $5 \mathrm{~min}$, followed by 35 cycles with and stored at $-20^{\circ} \mathrm{c}$ for conducting PCR. 
denaturation at $95^{\circ} \mathrm{c}-1 \mathrm{~min}, 72^{\circ} \mathrm{c}-30 \mathrm{sec}$ and $72^{\circ} \mathrm{c}-90$ seconds. A final extension step was also carried out at $72^{\circ} \mathrm{c}$, for $90 \mathrm{Sec}$.

\section{Analysis of PCR products}

Amplified PCR products were subjected to agarose gel electrophoresis as described by Sam brook and Russell (2001). PCR amplified product specific to $S$. aureus was visualized under U.V trans-illuminator and photographed with gel documentation system (BIO-RAD, Gel Doc $\left.{ }^{\mathrm{TM}}\right)$.

\section{DNA sequence analysis}

Amplified PCR products of 16SrRNA gene were sequenced and sequence analysis was done using NCBI BLAST for similarity and percent identity searches with the gene sequences available in the Gene bank. After confirmation of Staphylococcus aureus, the nucleotide sequences were submitted to gene bank through sequin submission portal for obtaining accession numbers. Nucleotide sequencing and Phylogenetic (Cluster) analysis was done by multiple sequence alignment using online software Clustal X 2.1. The phylogenetic analysis was done using the MEGA 6.06 program.

\section{Results and Discussion}

\section{Cultural isolation}

A total of 381 Staphylococcal isolates were recovered on cultural isolation with positivity of $86.98 \%$ from 438 milk samples collected from non therapeutic areas. Similarly, a total of 40 Staphylococcal isolates from therapeutic areas were obtained from 60 milk samples on cultural isolation with positivity of $66.67 \%$ (Table 1 ). Various workers reported the positivity rate of $80.98 \%$ from Maharastra (Yadav 2018) and Sanotharan et al. 2016 from Srilanka (90.5\%). However, Qudri et al.2017 recorded low positivity rate of 42.2 from Srinagar. Inconsistency and irrational use of antibiotics indicated the variations in positive percent of our findings and earlier studies from non therapeutic areas. Whereas, the positivity rate $(66.67 \%)$ of our study in the therapeutic areas were in coincidence with the earlier reports of Jyothi et al. (2018) from Hyderabad with 62.9\%; Bhat et al. (2017) from Jammu with $60.80 \%$ and Mubarak et al.(2012) from Tamilnadu with60.80\%. However, high prevalence was reported by Mpatswenumugab et al. (2017) from Rwanda with 72.1\% and Pati and Reena Mukherjiee (2016) from Uttar Pradesh with $71.87 \%$. Whereas low prevalence rate was recorded by Harini and Sumati 2011 from Karnataka (58\%) and $46.3 \%$ by Jena et al. 2015 from Rajasthan.

The variability in occurrence of $S$. aureus in mastitis cows among different reports might be that $S$.aureus is a contagious pathogen transmitted from one cow to another in a herd by contact via unhygienic milking procedures and poor farm management practices, environmental inconsistency and lack of awareness among dairy farmers.

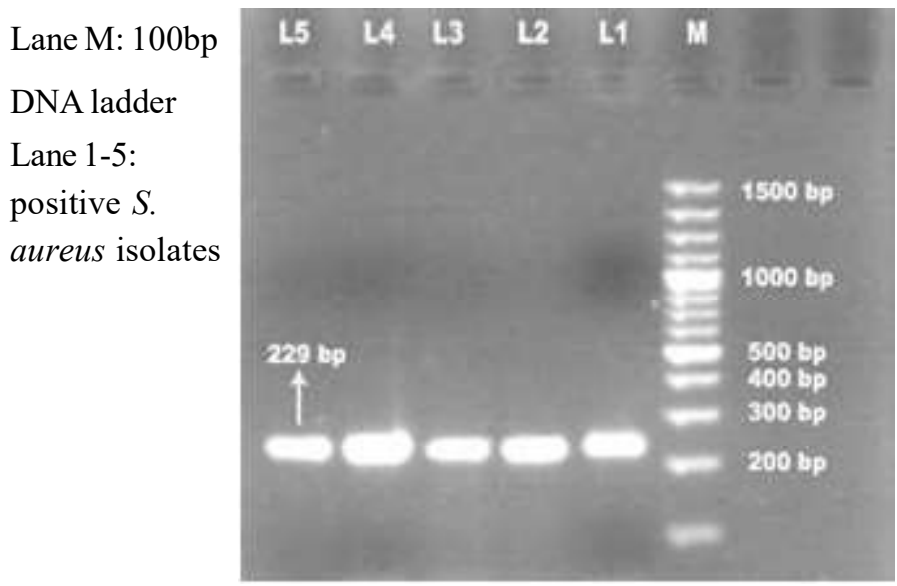

Fig. 1 PCR amplification of 16SrRNA gene of $S$. aureus isolates-Non therapeutic areas

All the 421 isolates from non therapeutic and therapeutic areas were shown hemolytic colonies on blood agar media; on mannitol salt agar media, yellow color round glistening colonies indicative of Coagulase Positive; pink color colonies indicative of Coagulase Negative and no growth on Macconkey's agar suggesting positive for $S$. aureus. On Gram's staining reaction all positive isolates revealed gram positive cocci with grape like clusters and biochemically positive to catalase test and negative to oxidase test.

Similarly, 271 isolates of S. aureus $(71.0 \%)$ out of 381 isolates from non therapeutic areas and 27 isolates out of 40 isolates from therapeutic areas were positive for Coagulase test

\section{Molecular Characterization of S.aureus isolates}

All the $S$. aureus isolates which positive phenotypically were subjected to genotypic confirmation using 16SrRNA PCR. Out of $381,291(73.5 \%)$ S. aureus isolates from non therapeutic areas (Fig 1) and 30 isolates (75\%) out of 40 S.aureus isolates from therapeutic areas yielded expected amplicon size of $229 \mathrm{bp}$ (Fig 2 ). It has been used by several workers (Pati and Reena Mukerjee, 2016; WHO 2015; Lange et al.2015; Ciftci et al. 2009; Zhang et al. 2004; Krimmer et al. 1999). During the present study the identification rate of 73.5 to $66.67 \%$ was reported and it was less than those reported by earlier workers Lange et al. 2015 (95\%); Pati and Reena Mukerjee 2016 (83.8\%) and Mellmann et al. 2006 $(91 \%)$ respectively.

The results of multiple nucleotide alignment of 16SrRNA gene of all the isolates (291) from non therapeutic areas showed nucleotide identity in the range of $99.3 \%$ with reference gene bank strain of Assam (Accession no.KP337596.1), Bihar strain (Accession no .MH 255793.1),UttarPradesh (Accession no. KX 181851.1), German (GU 459255.1), Spain (Accession no.KX 348312.1) and USA strain (KJ 83377.1). Similarly multiple nucleotide alignment of $16 \mathrm{Sr}$ RNA Gene of all the isolates from therapeutic 
Lane M: $100 \mathrm{bp}$ DNA ladder Lane 2-7: positive $S$. aureus isolates Lane 1: Negative control

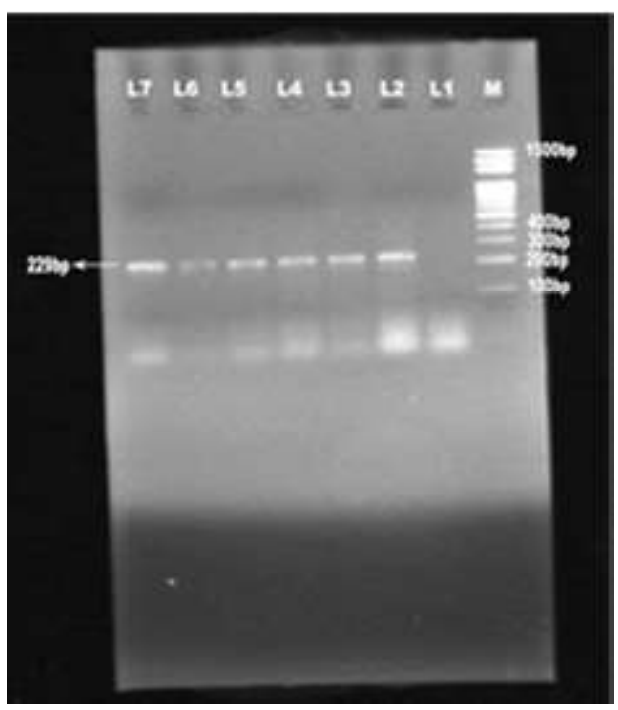

Fig. 2 PCR amplification of 16S rRNA gene of $S$. aureus isolates -Therapeutic areas

areas (LFC,SKP\&Peruru ) showed a nucleotide identity in the range of $95-100 \%$ on comparison with reference strains in the gene bank database. The partial 16Sr RNA Sequencing differentiated $95 \%$ of the isolates tested for species identification in the present study. The identification rate of $95 \%$ obtained in this study was higher than those reported by Mellmann et al. (2006) with 91\%.

On phylogenetic analysis, isolates from non therapeutic areas were not closely related to reference gene bank strains (Fig 3). Whereas isolates of therapeutic areas viz., Livestock Farm Complex (LFC) and Sorakayalapalem (SKP) shown close evolutionary relationship with gene bank reference strains. However, Peruru isolates have shown close evolutionary relationship with Spain isolate KX348312.1 and formed separate clade.

During the study, antibiotic sensitivity test was conducted on S. aureus isolates recovered from non therapeutic areas and selected therapeutic areas. The antibiotic sensitivity test results revealed that the isolates recovered from non therapeutic areas showed higher sensitivity to Amoxicilli 60.38\% (64/106) followed by Ampicillin 56.60\% (60/106), Enrofloxacin 53.77\% (57/ 106), Ciprofloxacin 46.23\% (49/106), Gentamycin $26.42 \%$ (28/ 106), Tetracycline 20.75\% (22/106),Streptomycin $12.26 \%(13 / 106)$ ,Kanamycin 9.43\% (10/106) and Amikacin 7.55\% (8/106\%) but were resistant to Amikacin $92.45 \%(98 / 106)$ followed by Kanamycin 90.57\%(96/106),Streptomycin 87.74\% (93/106), Tetracycline 79.25\%(84/106), Gentamycin 73.58\% (78/106), Penicillin-G 56.60\% (60/106), Ciprofloxacin 53.77\% (57/106), Enrofloxacin 46.23\% (49/ 106) Ampicilln 43.40\% (46/106) and Amoxicillin 39.62\% (42/106) respectively. This was in accordance with reports of Qayyum et al. (2016); Husssain et al. (2012a) and Idriss et al (2014). But in therapeutic areas higher sensitivity to Enrofloxacin $66.67 \%$

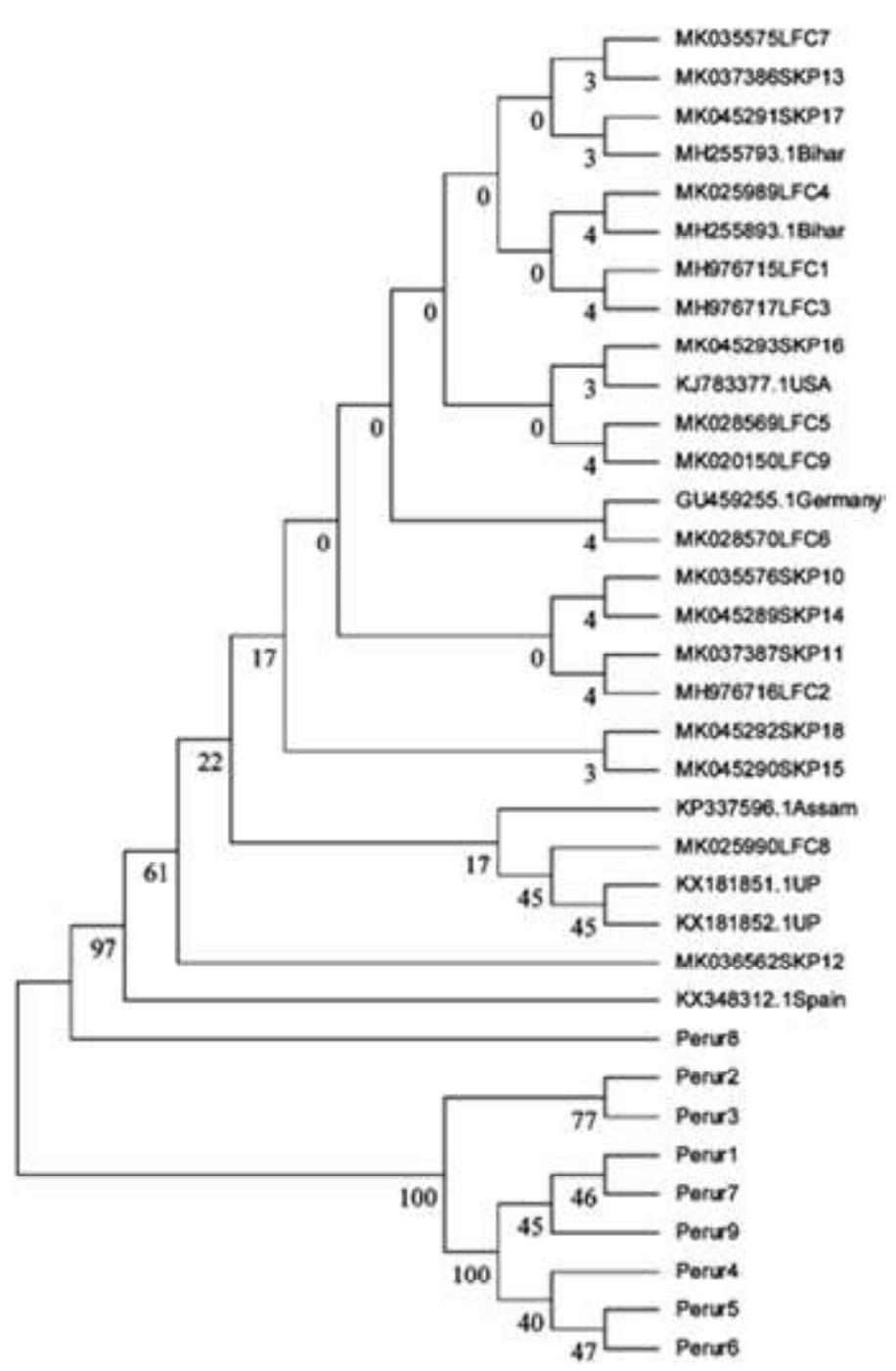

Fig.3 Phylogenetic analysis of $16 \mathrm{~S}$ rRNA gene of $S$. aureus isolates

followed by Ciprofloxacin 59.25\%, Amoxicillin 44.44\% and Ampicillin 40.74\%. Similar sensitivity pattern of $S$. aureus isolates to Enrofloxacin was reported by Baghel et al.2018; Dar et al. 2014; Bhanot et al. 2012 ; Kumar and Sharma 2002 ; Sahoo et al. 2009; Joshi et al. 2006 and Ranjan et al. 2010. It could be due to lesser usage of these antibiotics in majority of districts of Andhra Pradesh in treating the mastitis cases.

In the present study among Quinolones, Enrofloxacin $66.67 \%$ Ciprofloxacin 59.25\% and beta lactamase antibiotics like Amoxicillin 63.7\% and Ampicillin 56.6\% were found to be effective in therapeutic study areas. The extensive use of antibiotics in treatment and control of mastitis has possible implications on human heath through emergence of antibiotic resistant bacteria. The antibiotic sensitivity profile of isolated pathogens can serve as a guide for field veterinary practitioners to provide effective and timely treatment of mastitis cattle. 


\section{Conclusions}

The present work was undertaken with an objective of isolation and characterization of $S$. aureus from clinical and subclinical cases of bovine mastitis and to conduct antibiogram of all $S$. aureus isolates to know the antibiotic of choice for the treatment of bovine mastitis caused by S.aureus. Hence, the present study revealed the isolation, identification and phenotypic characterization of $S$. aureus strains by cultural and biochemical tests; genotypically using $16 \mathrm{SrRNAPCR}$. Further, it was reported that 16SrRNA PCR was found to be powerful and simple tool for the identification of $S$. aureus from bovine mastitis. Thus the findings of this study in non therapeutic and therapeutic areas would be helpful in detecting the existence and emergence of $S$. aureus isolates, antibiotic resistant pathogens and useful in selection of isolate for preparation of vaccine for effective control of clinical and sub clinical mastitis caused by $S$. aureus.

\section{Acknowledgement}

The authors gratefully acknowledge Sri Venkateswara Veterinary University, Tirupati for providing financial help in studying the mastitis cases in the districts of Andhra Pradesh

\section{References}

Arora S, Agarwal RK, Bist B (2006) Comparison of ELISA and PCR visa'-vis cultural methods for detecting Aeromonas spp. in foods of animal origin. Int J Food Microbiol 106: 177-183

Bhat A M, Soodan J S, Singh R, Dhobi I A, Hussain T, Dar M Y, Mir M (2017) Incidence of bovine clinical mastitis in Jammu region and antibiogram of isolated pathogens. Vet World 10: 984-989

Baghel A, Chhabra D, Sharda R, Shukla S, Audarya S, Sikrodia R, Gangil R (2018) Isolation of Staphylococcus from bovine mastitis and their antibiotic sensitivity pattern. Indian J Vet Sci. Biotech 13: 49-52

Bhanot V, Chaudhri SS, Bisla RS, Singh H (2012) Retrospective study on prevalence and antibiogram of mastitis in cows and buffaloes of eastern Haryana. Indian J Anim Res 46 : 160-163

Ciftci A, Findik A, Onuk E, Savasan S (2009) Detection of methicillin resistance and slime factor production of Staphylococcus aureus in bovine mastitis. Braz J Microbiol 40: 254-261

Cruickshank R, Duguid J P, Marmoin B P, Swain R H A (1975) Medical Microbiology, II 12th ed Churchill Livington, Edinburgh, London and New York

Dar K H, Ansari M M, Dar S H, Tantary H A, Baba M A, Naikoo M U D (2014) Studies on subclinical mastitis in dairy cows of Jammu and Kashmir. Inter J Vet Sci 3: 95-99

Hussain R, Khan A, Javed MT, Rizvi F (2012a) Possible risk factors associated with mastitis in indigenous cattle in Punjab and Pakistan. Pak Vet J 32: 605-608

Idriss SE, Foltys V, Tancin V, Kirchnerova K, Tancinova D, Zaujec K (2014) Mastitis pathogens and their resistance against antimicrobial agents in dairy cows in Nitra, Slovakia. Slovak J Anim Sci 47: 33-38

Jaradat ZW, Tarazi YH, Ababneh QO (2014) Molecular characterization of Staphylococcus aureus isolated from meat and their antibiotic resistance profiles. Pak Vet J 34: 58-62

Joshi S, Gokhale S (2006) Status of Mastitis as an Emerging Disease in Improved and Peri urban Dairy Farms in India. Ann New York Acad Sci 1081: 74-83
Harini H, Sumathi B R (2011) Screening of bovine milk samples for subclinical mastitis and antibiogram of bacterial isolates. Vet World 4: 358-359

Jena B, Pagrut NK, Sahoo A, Ahmed A (2015) Subclinical Bovine Mastitis in Rural, Peri-Urban and Suburban Regions of Jaipur District of Rajasthan. Indian J Anim Res 5: 175-182

Jyothi S, Putty K, Pushpa RNR, Umair H, Amol, Muley V, Dhanalakshmi K, Reddy YN

(2018) Antibiogram of Bacterial Isolates Obtained from Milk Samples in and Around Hyderabad, India. Int J Curr Microbiol App Sci 7: 37203724

Krimmer V, Merkert H, von Eiff C, Frosch M, Eulert J, Löhr J F (1999) Detection of Staphylococcus aureus and Staphylococcus epidermidis in clinical samples by $16 \mathrm{~S}$ rRNA-Directed In Situ Hybridization. J Clin Microbiol 37: 2667-73

Kalorey D R, Shanmugam Y, Kurkure N V, Chousalkar K K, Barbuddhe S B (2007) PCR based detection of genes encoding virulence determinants in Staphylococcus aureus from bovine subclinical mastitis cases. J Vet Sci 8: 151-154

Kumar R, Sharma A (2002) Prevalence, etiology and antibiograms of mastitis in cows and buffaloes in Hisar, Haryana. Indian J Ani Sci 72: 361-363

Lange CC, Brito MAVP, Reis DRL, Machado MA, Guimarães S, Azevedo ALS, Meurer IR (2015) Species-level identification of Staphylococci isolated from bovine mastitis in Brazil using partial 16S rRNA sequencing. Vet Microbiol 176: 382-388

Lovseth A, Loncarevic S, Berdal KG (2004) Modified Multiplex PCR Method for detection of Pyrogenic Exotoxin Genes in Staphylococcal Isolates. J Clin Microbiol 42 :3869-3872

Mellmann A, Becker K, Von Eiff C, Keckevoet U, Schumann P, Harm-sen D (2006) Sequencing and Staphylococci identification. Emerg Infect Dis $12: 333-336$

Mpatswenumugabo P, Bebora L C, Gitao G C, Mobegi VA, Iraguha B, Kamana O,Shumbusho B (2017) Prevalence of Subclinical Mastitis and Distribution of Pathogens in Dairy Farms of Rubavu and Nyabihu Districts, Rwanda. J Vet Med 1-8

Mubarack H M, Doss A, Vijayasanthi M, Venkataswamy R (2012) Antimicrobial Drug Susceptibility of Staphylococcus aureus from Subclinical Bovine Mastitis in Coimbatore, Tamilnadu, South India. Vet World 5: 352-355

Padhy A, Dalai N, Shekhar S, Sahu AR, Sahoo S, Kashyap DK (2014) A Microbial, Antibiogram and Haematological Study of Mastitic Cows. J Cell Tissue Res 4: 4681-4684

Pati BK, Mukherjee R (2016) Characterization of Staphylococcus aureus Isolates of Bovine Mastitis Origin and Antibiotic Sensitivity Pattern from Northern Plains of India. J Vet Res Ani Husb 1: 1-5.

Qadri S I A, Shaheen M, Baig SU, Malik H, Bhat ZI, Bhat IA, Dar PA, Yousuf RW, Iqbal RM (2017) Aetio-Prevalence Study on Bovine Sub Clinical Mastitis in Lactating Jersey Cross-Bred Cows. Int J Curr Microbiol App Sci 6: 3354- 3357

Qayyum A, Khan JA, Hussain R, Khan A, Avais M, Ahmad N \& Hassan MF (2016) Molecular characterization of Staphylococcus aureus isolates recovered from natural cases of subclinical mastitis in cholistani cattle and their antibacterial susceptibility. Pak J Agri Sci 53: 1-6

Quinn PJ, Carter ME, Markey BK ,Carter GR (1999) Veterinary Microbiology, Mosby, Harcourt Publishers Limited, Europe.

Radostits OM, Gay CC, Blood DC, Hinchllif KW Mastitis, Veterinary Medicine (2007) 9th ed, Haracourt Ltd, London. pp 174-758

Raza A, Muhammad G, Sharif S, Atta A (2013) Biofilm producing Staphylococcus aureus and bovine mastitis: A review. Mol Microbio Res 1:1-8 
Ranjan R, Gupta MK, Singh S,Kumar S (2010) Current trend of drug sensitivity in bovine mastitis. Veterinary World 3: 17-20

Sanotharan N, Pagthinathan M, Nafees M S M (2016) Prevalence of Bovine Subclinical Mastitis and its Association with Bacteria and Risk Factors in Milking Cows of Batticaloa District in Sri Lanka. Int J Sci Res Innov Tech 3:137-150

Saei HD, Ahmadi M, Mardani K, Batavani RA (2009) Molecular typing of Staphylococcus aureus isolated from bovine mastitis based on polymorphism of the coagulase gene in the North West of Iran. Vet Microbiol 137: 202-206

Sahoo SS, Sahoo N, Parida S (2009) Antibiogram of bacterial isolates from bovine subclinical mastitis. Indian Vet J 86 :1298-1299

Sambrook J, Russell DW (2001) Commonly used techniques in molecular cloning, Molecular Cloning: A Laboratory Manual, 3rd ed

World Health Organization (2015) Ten facts on antimicrobial resistance
Yadav (2018) Prevalence of Staphylococcus aureus in Lactating Cows with Subclinical Mastitis and their Antibiogram in Organized Dairy Farm, Maharashtra, India Int J Curr Microbiol App Sci 7: 36743680

Zhang K, Sparling J, Chow BL, El sayed S, Hussain Z, Church DL, Conly JM (2004) New Qua driplex PCR assay for detection of methicillin and mupirocin resistance and simultaneous discrimination of Staphylococcus aureus from Coagulase-Negative Staphylococci. J Clin Microbiol 42: 4947-4955 